\title{
School menus in Santa Catarina: Evaluation with respect to the National School Food Program regulations
}

\author{
Cardápios escolares em Santa Catarina: avaliação \\ perante a regulamentação do Programa \\ Nacional de Alimentação Escolar
}

Glenda Marreira VIDAL ${ }^{1,2}$

Marcela Boro VEIROS ${ }^{1}$

Anete Araújo de SOUSA ${ }^{1,2}$

A B S T R A C T

\section{Objective}

To assess compliance of school menu planning with the National School Food Program's regulations.

\section{Methods}

This cross-sectional study analyzed 133 menus for 542 schools in 49 municipalities of the state of Santa Catarina. The menus were assessed according to the National School Food Program's regulations, the "Dietary Guidelines for the Brazilian Population" and the "Qualitative Evaluation of Menu Components for Schools". The data were analyzed by descriptive statistics.

\section{Results}

Nearly all (98.5\%) municipalities met the requirement of technical responsibility for menu development and $81.0 \%$ acquired foods from family farms. The menus contained fruits (87.2\%) and non-starchy vegetables $(94.0 \%)$, but the frequencies of fruits and non-starchy vegetables were smaller than two to three times a week. The most common high-sodium and high-fat foods were commercially processed meats (53.0\%), but their frequency was smaller than once a week. Likewise, the frequencies of beverages (natural fruit juice, coffee, and

1 Universidade Federal de Santa Catarina, Programa de Pós-Graduação em Nutrição, Núcleo de Pesquisa de Nutrição em Produção de Refeições. Campus Universitário, Sala n² 205, Caixa Postal 476, Trindade, 88040-970, Florianópolis, SC, Brasil. Correspondência para/Correspondence to: AA SOUSA.E-mail: <anete.sousa@ufsc.br>.

2 Centro Colaborador em Alimentação e Nutrição do Escolar de Santa Catarina. Florianópolis, SC, Brasil. Article based on the master's thesis of GM VIDAL, intitled "Avaliação de cardápios com alimentos orgânicos da alimentação escolar em municípios de Santa Catarina". Universidade Federal de Santa Catarina; 2013.

Support: Universidade Federal de Santa Catarina, Coordenação de Aperfeiçoamento de Pessoal de Nível Superior, Fundo Nacional de Desenvolvimento da Educação (Process n 234000.000675/2010-21) and Centro Colaborador em Alimentação e Nutrição do Escolar do Estado de Santa Catarina. 
tea) were smaller than once a week. Most menus (85.1\%) repeated foods during the week, and only $3.0 \%$ of the menus listed organic foods.

\section{Conclusion}

Some school menus from Santa Catarina need to be revised with respect to the frequency of fruits and non-starchy vegetables, high-sugar foods, high-sodium foods, and high-fat foods, and need to increase food diversity and variety.

Keywords: Legislation, food. Menu planning. Organic foods. School food.

\section{R E S U M O}

\section{Objetivo}

Avaliar a adequação do planejamento de cardápios escolares perante a regulamentação do Programa Nacional de Alimentação Escolar.

\section{Métodos}

Trata-se de estudo que transversal, que analisou 133 cardápios, de 49 municípios catarinenses, que atendiam a 542 escolas. Os cardápios foram avaliados com base na regulamentação do Programa Nacional de Alimentação Escolar, no Guia Alimentar para a população brasileira e no Método de Avaliação Qualitativa das Preparações do Cardápio Escolar. Os dados foram analisados através de estatística descritiva.

\section{Resultados}

A exigência de responsabilidade técnica pela elaboração do cardápio foi observada em 98,5\% dos municípios, e $81 \%$ adquiriam alimentos da agricultura familiar. Os cardápios apresentaram frutas (87,2\%) e hortaliças (94,0\%), no entanto mais da metade teve frequência de frutas e hortaliças inferior a duas ou três vezes por semana. A presença de alimentos e preparações ricas em açúcar foi elevada (>90\%), predominando frequência de até duas vezes por semana. Dos alimentos ricos em sódio e gorduras, destacaram-se embutidos e produtos cárneos industrializados (53,0\%), porém a frequência foi inferior a uma vez por semana. As bebidas nos cardápios (suco de fruta natural, café e chá) tiveram frequência inferior a uma vez por semana. A repetição de alimentos na mesma semana foi observada em $85,1 \%$ dos cardápios. Já a identificação do alimento orgânico foi encontrada em apenas 3,0\% deles.

\section{Conclusão}

Alguns cardápios da alimentação escolar catarinense necessitam de revisão quanto à frequência de frutas e hortaliças, redução de alimentos ricos em açúcar, sódio e gorduras e de aumento na diversidade e variedade de alimentos.

Palavras-chave: Legislação sobre alimentos. Planejamento de cardápio. Alimentos orgânicos. Alimentação escolar.

\section{NTRODUCTION}

A healthy and proper diet is a food practice appropriate for individuals' biological and sociocultural aspects. It is based on the production of sustainable foods that reduce physical, chemical, and biological contaminants, are referenced by the food culture, and are physically accessible, affordable, and harmonious in quantity and quality ${ }^{1,2}$.

Intake of fresh or minimally processed vegetables, such as rice, beans, cassava, potato, fruits, and non-starchy vegetables should be the basis of an appropriate and healthy $\operatorname{diet}^{3}$. On the other hand, one should avoid consuming too much sugar, sodium, and saturated fats, because these items are associated with the risk of developing Chronic Noncommunicable Diseases (NCD), such as diabetes, hypertension, and cancer $^{4}$.

The promotion of healthy food practices among schoolchildren and adolescents is encouraged because it allows perpetuating good life habits throughout adulthood, providing greater protection against NCD ${ }^{5}$. 
Data from the 2009 National Schoolchild Health Survey (Pesquisa Nacional de Saúde do Escolar, 2009) show low intake of healthier foods, such as beans, fruits, non-starchy vegetables, and milk, and regular intake of less healthy foods, such as deep-fried foods, cookies, sandwich cookies, soda, sweets, and commercially processed meats by Brazilian schoolchildren in the last year of elementary school ${ }^{6,7}$. These data evidence the need of promoting a healthy diet among this population.

In this scenario, the Programa Nacional de Alimentação Escolar (PNAE, National School Food Program) is considered an strategic public policy for the food and nutrition security of schoolchildren, guided by the Human Right to Adequate Food (HRAF) $)^{1,8}$.

Law $n^{\circ} 11.947 / 2009^{9}$ of the Fundo Nacional de Desenvolvimento da Educação (FNDE, National Education Development Fund) regulated by Resolution $n^{\circ} 38 / 2009^{10}$ made important advances by incorporating cultural and social dimensions in school menu planning, such as requiring the purchase of foods produced by family farms with at least $30 \%$ of the funds given to the states and municipalities, prioritizing organic and/or agroecological foods. Another fundamental aspect is the required presence of at least three servings a week of fruits and nonstarchy vegetables in the menus ${ }^{9}$; restriction of foods with high simple sugar, sodium, saturated fat, trans fat, and cholesterol contents; and the banning of nutrient-scarce beverages ${ }^{9,10}$.

Other recent public policies that support family farms are compatible and align with PNAE by promoting healthy food practices ${ }^{1}$ and by encouraging the intake of fresh regional foods that promote social- and biodiversity. Among the policies, the Politica Nacional de Agroecologia e Produção Orgânica (PNAPO, National Agroecology and Organic Production Plan) emphasizes the relationship between an appropriate and healthy diet and the production systems of sustainable foods, incorporating socio-environmental and cultural values ${ }^{11}$.
The intake of organic and/or agroecological foods is associated with health benefits for consumers, producers, and the environment. Add to these benefits the patronizing of small farmers and promotion of biodiversity and local sustainable development, guaranteeing higher demand and supply of organic foods at fair prices for individual and institutional consumers ${ }^{12}$. On the other hand, the use of pesticides by conventional agriculture can contribute to soil and water contamination, disturb ecological processes, damage beneficial microorganisms, and cause health problems in producers and consumers $^{13}$.

In summary, supplying meals that meet the nutritional requirements of schoolchildren by including foods produced by family farmers and prioritizing organic, agroecological, local, and regional foods, respecting the local habits and culture as recommended by $\mathrm{PNAE}^{9}$, are two measures that can potentially encourage healthy and sustainable school food.

Studies that analyzed planned school menus before Law $n^{\circ} 11.947 / 2009^{9}$ went into force investigated quantitative indicators (energy and micro- and macronutrients) ${ }^{14,15}$. Hence, only a few studies assessed planned menus based on PNAE's recent regulation changes ${ }^{16-18}$, justifying the relevance of monitoring menus that follow such regulations.

Given this gap, the objectives of the present study were to assess the adequacy of the planned school menus regarding PNAE's regulations; to qualitatively assess the preparations in the menu; to identify the presence of organic foods and preparations containing organic foods in the menu; and to determine their frequency in the menu.

\section{METHODS}

This cross-sectional study assessed 133 menus (98 planned monthly and 35 planned weekly) planned for 542 elementary schools in 
49 municipalities in the state of Santa Catarina that bought organic foods in 2010 .

According to a study done by the Centro Colaborador em Alimentação e Nutrição do Escolar de Santa Catarina (Cecane/SC, Collaborating Center for Santa Catarina's Schoolchild Food and Nutrition) in 2010, from the 293 municipalities in the state, 52 reported buying organic foods for school meals ${ }^{19}$. When visiting these municipalities, Cecane/SC asked the Departments of Education for PNAE's menus of 2010. They collected menus from all months in 2010. Forty-nine municipalities provided elementary school menus, totaling 133 menus.

An instrument based on Resolution $n^{\circ}$ $38 / 2009^{10}$, the Dietary Guidelines for the Brazilian Population ${ }^{1}$ and the Qualitative Evaluation of Menu Components for Schools (QEMC School) ${ }^{20}$ was prepared for assessing the menus.

The instrument covered the following variables and indicators:

- Municipality characteristics (geographical region and size according to the classification provided by the Brazilian Institute of Geography and Statistics, in 2010)21;

- Having a dietician in charge of the PNAE and menu planning;

- Purchase of foods produced by family farms and use of at least $30 \%$ of the funds provided by FNDE for buying such foods;

- Purchase of organic foods and identification of their use in the menu;

- Quality of the information available in the menu (specification of the type of food and how it was prepared; presentation of complementary information: recipe and list of replacements and ingredients, among others);

- Weekly repetition of foods, preparations, and preparation techniques;

- Presence of fruits and non-starchy vegetables at least three times a week.

We also estimated the presence and weekly frequency of 20 food and beverage categories in the school menus defined by QEMC School ${ }^{20}$, the the Dietary Guidelines for the Brazilian Population', and Resolution $n^{\circ}$ 38/20099. These categories were: 1) Fresh fruits and fruitbased preparations; 2) Non-starchy vegetables and non-starchy vegetable-based preparations; 3 ) Grains, bread, pasta, tubers, and roots; 4) Legumes; 5) Milk and dairy products; 6) Meats and eggs; 7) Condiments and seeds; 8) Oils and fats; 9) Preparations with added sugar; 10) Products with added sugar; 11) Commercially processed meats; 12) Canned foods and preserves; 13) Ready-to-eat or almost ready-toeat foods; 14) Commercially prepared concentrated, powdered, or dehydrated foods; 15) Natural fruit juices; 16) Drink mixes; 17) Powdered drink mixes; 18) Soda; 19) Coffee; 20) Tea.

The data were entered in Microsoft Office Excel 2007 and subsequently transferred to the software Stata 11.0 (Stata Corp., College Station, United States) for the statistical analyses.

The frequency was given by the weekly presence of the different food and beverage categories, that is, by dividing the total number of times that the category appeared in the menu divided by the number of weeks in the menu. Finally, the frequency was classified in increasing order: <once a week; 1 to $<2$ times a week; 2 to $<3$ times a week; 3 to $<4$ times a week; 4 to $<5$ times a week; and 5 times a week.

The data were analyzed by descriptive analysis expressed as absolute and relative frequencies.

The project was approved by the Human Research Ethics Committee of the Univerdade Federal de Santa Catarina under Protocol $n^{\circ}$ $1005 / 2010$.

\section{RES U LT S}

The number of menus provided by the municipalities ranged from one to thirteen, totaling 133 menus for 542 elementary schools 
in 49 municipalities, but most municipalities (51.0\%) provided only one menu. A total of 356 preparations were assessed. Most menus followed the following standard: small meals consisting of fruit-based meals or fruit juice accompanied by cookies, bread, or cake on two to three weekdays; and large meals composed of non-starchy vegetables, a protein source, rice or pasta or starchy vegetables without dessert (fruit/sweet) on the other two or three weekdays. Most menus were from small municipalities $(79.6 \%)$ in the western region of the state $(49.9 \%)$, and most $(93.9 \%)$ had a dietician in charge of the PNAE. Nearly all menus had been planned by a dietician (98.5\%); the remainder had been planned by the school principal or the first lady. Most menus were from municipalities that acquired foods produced by family farms $(87.2 \%)$ or the amount of food required by FNDE (81.0\%).

Although most study menus originated in municipalities that claimed having acquired organic foods for the school meals, only $3 \%$ pointed out the presence of organic food in the menu preparations. The listed foods and preparations were: organic bean soup, organic bean viradinho (beans mixed with corn meal), organic beans, organic fruits (fruits not specified), and organic salads (vegetables not specified).

Regarding the quality of the information available in the menus, $22.6 \%$ of the menus contained a full daily specification of the types of foods, and only $3.7 \%$ specified how the foods were prepared. Most menus did not standardize the specification and/or provide complete information about the type of food $(45.1 \%)$ and preparation technique (43.6\%). For example, some meals did not describe the type of fruit they contained, mentioning only "fruit" in the menu, and other meals did not specify the preparation technique, mentioning only "steak" or "chicken".

Fewer than $18 \%$ of the menus were provided with some sort of complementary information attached to them, such as a list of the amount of food per capita, list of ingredients, and calculation of the nutritional value of the meals. Table 1 shows the list of the 20 food and beverage categories in the study menus.

Most menus contained healthy food categories, such as fruits and non-starchy vegetables (87.2 and $94.0 \%$, respectively). The fruits seen most frequently in the menus were: banana $(48.9 \%)$, apple $(36.9 \%)$, and orange $(18.8 \%)$. The main non-starchy vegetables were: cabbage $(44.4 \%)$, lettuce $(39.1 \%)$, carrot $(37.6 \%)$, tomato $(12.8 \%)$, and cauliflower (12.0\%).

Only $6.0 \%$ of the menus contained whole foods. The specified whole foods were: whole rice, oats, bread, and cookies. Many foods in the menu contained sugar added by the schools ( $91.0 \%)$, such as cake, porridge, and fruit shake; and commercially processed high-sugar foods (92.5\%), especially chocolate milk and cookies.

The menus also contained high-sodium foods: $2.3 \%$ consisting of almost or ready-to-eat foods, such as tomato sauce; $11.3 \%$ consisting of canned foods or preserves (sardine, pea, and corn); $53.0 \%$ consisting of commercially processed meats, especially hot dog sausage and mortadella; and $76.7 \%$ consisting of powdered, concentrated, or dehydrated foods, such as cocoa powder and gelatin desserts. The only beverages in the menus were natural fruit juice, coffee, and tea. Table 2 shows the weekly frequency of the study food and beverage categories.

The frequency of whole grains, bread, and pasta, tubers, and legumes was low in most menus (served less than once a week). Fruits and non-starchy vegetables were present fewer than three and four times a week, respectively.

Regarding the frequency of food categories containing simple sugars, preparations with added sugar were present fewer than twice a week $(41.3 \%)$, and high-sugar processed foods were present fewer than three times a week (33.1\%). Foods with high sodium and high fat (saturated, total, and trans) contents, such as commercially processed meats, were present fewer than once a week. 
Table 1. Presence of food and beverage groups in the municipal menus of Santa Catarina in $2010(n=133)$.

\begin{tabular}{|c|c|c|c|c|}
\hline \multirow{2}{*}{ Food and beverage groups } & \multicolumn{2}{|c|}{ Yes } & \multicolumn{2}{|c|}{ No } \\
\hline & $\mathrm{n}$ & $\%$ & $\mathrm{n}$ & $\%$ \\
\hline Fruits and respective preparations & 116 & 87.2 & 17 & 12.8 \\
\hline Non-starchy vegetables and respective preparations & 125 & 94.0 & 8 & 6.0 \\
\hline Whole grains & 7 & 5.3 & 126 & 94.7 \\
\hline Refined grains & 130 & 97.7 & 3 & 2.3 \\
\hline Whole bread and pastry & 7 & 5.3 & 126 & 94.7 \\
\hline Refined bread and pastry & 120 & 90.2 & 13 & 9.8 \\
\hline Whole pasta & 0 & 0.0 & 133 & 100.0 \\
\hline Refined pasta & 120 & 90.2 & 13 & 9.8 \\
\hline Tubers and roots & 89 & 67.0 & 44 & 33.0 \\
\hline Legumes & 122 & 91.7 & 11 & 8.3 \\
\hline Milk and dairy products & 125 & 94.0 & 8 & 6.0 \\
\hline Meats and eggs & 129 & 97.0 & 4 & 3.0 \\
\hline Condiments and seeds & 5 & 3.8 & 128 & 96.2 \\
\hline Oils and fats & 40 & 30.1 & 93 & 69.9 \\
\hline Preparations with added sugar & 121 & 91.0 & 12 & 9.0 \\
\hline Products with added sugar & 123 & 92.5 & 10 & 7.5 \\
\hline Commercially processed meats & 70 & 53.0 & 63 & 47.0 \\
\hline Almost and ready-to-eat foods & 3 & 2.3 & 130 & 97.7 \\
\hline Canned products and preserves & 15 & 11.3 & 118 & 88.7 \\
\hline Powdered foods & 102 & 76.7 & 31 & 23.3 \\
\hline Natural fruit juices & 87 & 65.4 & 46 & 34.6 \\
\hline Drink mixes & 0 & 0.0 & 133 & 100.0 \\
\hline Powdered drink mixes & 0 & 0.0 & 133 & 100.0 \\
\hline Soda & 0 & 0.0 & 133 & 100.0 \\
\hline Coffee & 43 & 32.3 & 90 & 67.7 \\
\hline Tea & 25 & 18.8 & 108 & 81.2 \\
\hline
\end{tabular}

\section{DISCUSSION}

This study collected school menu planning data from 49 municipalities of Santa Catarina. All of them reported acquiring organic foods for the school meals in 2010.

More than $80.0 \%$ of the study menus were from municipalities that acquired at least $30.0 \%$ of their foods from family farms, as required by law. Saraiva et al. ${ }^{22}$ analyzed 2010 data regarding the purchase of foods from family farms in Brazilian municipalities and states and found that the national purchase percentage was $47.4 \%$, less than the percentage observed herein. Some of the difficulties associated with the acquisition of family farm foods are: family farmers do not issue invoices; family farms do not provide a regular and constant food supply; and the sanitary conditions are inadequate.
Gabriel et al. ${ }^{18}$ analyzed PNAE's menu planning in two Brazilian state capitals, Florianópolis (SC) and Belém (PA). The study capitals did not buy foods from family farms. The justification was a food supply that did not meet the demand of these cities and producers' lack of structure, preventing a regular food supply and issuance of the required documents.

All study menus were from municipalities that claimed to buy organic foods for the school meals. However, the menus usually failed to indicate their presence and type. The results evidenced the need of valuing the information regarding the presence of these foods in the planned menus, in addition to increasing their use given their relationship with healthy food practices in their social, environmental, and cultural dimensions. On the other hand, Silva \& Sousa ${ }^{19}$ used the same database as the present study and 
Table 2. Weekly frequency of food and beverage groups in the municipal menus of Santa Catarina in $2010(n=133)$.

\begin{tabular}{|c|c|c|c|c|c|c|c|c|c|c|c|c|}
\hline \multirow{2}{*}{ Food and beverage groups } & \multicolumn{2}{|c|}{$<1$} & \multicolumn{2}{|c|}{1} & \multicolumn{2}{|c|}{2} & \multicolumn{2}{|c|}{3} & \multicolumn{2}{|c|}{4} & \multicolumn{2}{|c|}{5} \\
\hline & $\mathrm{n}$ & $\%$ & $n$ & $\%$ & $\mathrm{n}$ & $\%$ & $\mathrm{n}$ & $\%$ & $\mathrm{n}$ & $\%$ & $n$ & $\%$ \\
\hline Fruits and respective preparations & 33 & 24.8 & 50 & 37.6 & 35 & 26.3 & 13 & 9.8 & 1 & 0.8 & 1 & 0.8 \\
\hline $\begin{array}{l}\text { Non-starchy vegetables and } \\
\text { respective preparations }\end{array}$ & 15 & 11.3 & 12 & 9.0 & 26 & 19.6 & 46 & 34.6 & 20 & 15.0 & 14 & 10.5 \\
\hline Whole grains & 133 & 100.0 & 0 & 0.0 & 0 & 0.0 & 0 & 0.0 & 0 & 0.0 & 0 & 0.0 \\
\hline Refined grains & 8 & 6.0 & 59 & 44.4 & 50 & 37.6 & 9 & 6.8 & 4 & 3.0 & 3 & 2.3 \\
\hline Whole bread and pastry & 133 & 100.0 & 0 & 0.0 & 0 & 0.0 & 0 & 0.0 & 0 & 0.0 & 0 & 0.0 \\
\hline Refined bread and pastry & 65 & 48.9 & 57 & 42.9 & 10 & 7.5 & 1 & 0.8 & 0 & 0.0 & 0 & 0.0 \\
\hline Whole pasta & 133 & 100.0 & 0 & 0.0 & 0 & 0.0 & 0 & 0.0 & 0 & 0.0 & 0 & 0.0 \\
\hline Refined pasta & 84 & 63.2 & 47 & 35.3 & 2 & 1.5 & 0 & 0.0 & 0 & 0.0 & 0 & 0.0 \\
\hline Tubers and roots & 106 & 79.7 & 22 & 16.5 & 2 & 1.5 & 3 & 2.3 & 0 & 0.0 & 0 & 0.0 \\
\hline Legumes & 62 & 46.6 & 59 & 44.4 & 9 & 6.8 & 1 & 0.8 & 1 & 0.8 & 1 & 0.8 \\
\hline Milk and dairy products & 20 & 15.0 & 73 & 54.9 & 36 & 27.0 & 3 & 2.3 & 1 & 0.8 & 0 & 0.0 \\
\hline Meats and eggs & 7 & 5.3 & 35 & 26.3 & 54 & 40.6 & 29 & 21.8 & 6 & 4.5 & 2 & 1.5 \\
\hline Condiments and seeds & 132 & 99.2 & 1 & 0.8 & 0 & 0.0 & 0 & 0.0 & 0 & 0.0 & 0 & 0.0 \\
\hline Oils and fats & 123 & 92.5 & 9 & 6.8 & 1 & 0.8 & 0 & 0.0 & 0 & 0.0 & 0 & 0.0 \\
\hline Preparations with added sugar & 34 & 25.6 & 55 & 41.3 & 32 & 24.1 & 8 & 6.0 & 3 & 2.3 & 1 & 0.8 \\
\hline Products with added sugar & 26 & 19.6 & 43 & 32.3 & 44 & 33.1 & 15 & 11.3 & 3 & 2.3 & 2 & 1.5 \\
\hline Commercially processed meats & 126 & 94.7 & 7 & 5.3 & 0 & 0.0 & 0 & 0.0 & 0 & 0.0 & 0 & 0.0 \\
\hline Almost and ready-to-eat foods & 130 & 97.7 & 3 & 2.3 & 0 & 0.0 & 0 & 0.0 & 0 & 0.0 & 0 & 0.0 \\
\hline Canned foods and preserves & 132 & 99.2 & 1 & 0.8 & 0 & 0.0 & 0 & 0.0 & 0 & 0.0 & 0 & 0.0 \\
\hline Powdered foods & 101 & 75.9 & 29 & 21.8 & 2 & 1.5 & 1 & 0.8 & 0 & 0.0 & 0 & 0.0 \\
\hline Natural fruit juice & 113 & 85.0 & 12 & 9.0 & 8 & 6.0 & 0 & 0.0 & 0 & 0.0 & 0 & 0.0 \\
\hline Drink mixes & 133 & 100.0 & 0 & 0.0 & 0 & 0.0 & 0 & 0.0 & 0 & 0.0 & 0 & 0.0 \\
\hline Powdered drink mixes & 133 & 100.0 & 0 & 0.0 & 0 & 0.0 & 0 & 0.0 & 0 & 0.0 & 0 & 0.0 \\
\hline Soda & 133 & 100.0 & 0 & 0.0 & 0 & 0.0 & 0 & 0.0 & 0 & 0.0 & 0 & 0.0 \\
\hline Coffee & 123 & 92.5 & 10 & 7.5 & 0 & 0.0 & 0 & 0.0 & 0 & 0.0 & 0 & 0.0 \\
\hline Tea & 132 & 99.2 & 1 & 0.8 & 0 & 0.0 & 0 & 0.0 & 0 & 0.0 & 0 & 0.0 \\
\hline
\end{tabular}

identified a great variety and diversity of these products produced by local family farmers and included in school meals, which may represent a real advancement for increasing sustainable food and agriculture systems and schoolchild access to healthy, culturally referenced foods.

Lima \& Sousa ${ }^{23}$ analyzed the introduction of organic foods in the meals of a school in Santa Catarina and found organic foods present in 33\% $(n=7)$ of the menu days. The authors also verified that to increase the amount of organic foods in the menu, the purchases would have to be better planned.

A study that analyzed 684 suggestions to facilitate the purchase of organic foods from family farms made by 446 social actors involved in the PNAE in Santa Catarina identified the following: need of sensitization strategies for the use of organic foods, with emphasis on educating and sensitizing social actors and community; better government management of the program, especially less bureaucracy and taxes, more outsourcing, and more manager involvement; organization of the supply and demand of organic foods given the logistic difficulties and management of meal production because of the required volume of a certain harvested food and diversity of organic foods ${ }^{24}$.

In the present study, some menus did not contain all the required information, such as specification of the food and preparation technique. On the one hand, the absence of specification can be a strategy to make the menu flexible and adaptable to the foods available at different times, allowing the purchase of seasonal foods such as fruits and vegetables. On the other 
hand, it limits the ability of the menu of informing the school community and schoolchildren which foods will be available.

However, menus planned in this fashion, aiming to meet the supply and seasonality of organic and/or agroecological foods, for example, could result in transferring the responsibility of food selection, preparation techniques, food combinations, and serving sizes from dieticians to cooks. These, in turn, need systematic education to carry out dietician-related activities ${ }^{25}$.

Neelon et al. ${ }^{26}$ compared the information in the planned menu with the actual meals. They concluded that the inaccuracy of the information in the planned menu is a limiting factor for assessing meal quality, since foods and preparation techniques may change as needed, which may significantly change the nutritional and sensory quality of the menus. Hence, the absence of specification in the menu can represent a risk to the nutritional and sensory quality of the meals.

Some menus did not contain fruits (12.8\%) or non-starchy vegetables $(6.0 \%)$, which is far from the World Health Organization (WHO) recommendation of $400 \mathrm{~g}$ per day of these foods to prevent $\mathrm{NCD}^{27}$.

Teo \& Monteiro ${ }^{28}$ state that the frequency of fruits and non-starchy vegetables recommended by PNAE should be increased to at least one serving per meal. This change in the legislation would promote the daily supply of these foods in the menus, helping to improve the nutritional quality of school meals and increase the benefits for farmers from the increased demand, and consequently, from the purchase of foods produced by family farms.

The present study also found a high frequency of milk and dairy products and a low frequency of whole grains, evidencing the need of revising the menus to increase the supply of whole grains. The same was observed by Condon et al. ${ }^{29}$. They assessed 1,915 menus from American public schools and found milk in $100 \%$ of the menus and whole bread in only $5 \%$ of the menus.
Data analysis faced some challenges because of the absence of information regarding the preparations and specification of the foods in a meal. For example, some menus contained generic information, such as "fruit," "salad," "soup," and "risotto," among others. Additionally, the preparation technique was also often absent with the menus mentioning only the type of protein source or cut, such as "beef," "chicken," and "meat," among others.

In the present menu, menu assessment was limited to analysis of the information described in the planned menus provided by the municipal departments of education. However, these menus could have been changed before they were executed, especially menus that did not present an appropriate description of the preparations to allow appropriate or coherent execution, thus requiring guidance and recommendations.

The study menus were collected at an earlier time by Cecane/SC (2010), which impaired us from obtaining complementary information in recipe cards. Therefore, the analyses were limited to the ingredients of the listed preparations without having consulted the actual recipes.

It is noteworthy that only a few studies assessed planned menus as recommended by FNDE's ${ }^{12}$ Resolution $n^{\circ} 38$ passed in 2009 because of recent changes in the legislation regarding the development of PNAE menus. This aspect limits the comparison of data found in the present research.

Given the number of study menus (133) and preparations (356), the results may reveal a profile of the municipalities of Santa Catarina that acquired organic foods for school meals.

The data of the present study show inadequacies regarding the quality of the information present in the menus, such as absence of standardization in the specification and/or incomplete information regarding type of food and preparation technique. 
Future studies should continue to assess the legal requirements for planning school menus taking into account the most recent recommendations published in Resolution $n^{\circ} 26$, passed on June 17, 2013 30 . Among other advances, the said resolution determines that menu planning should be based on the recipes, should specify the type of meal, preparation name, ingredients, and consistency, and should provide nutritional information (energy, macronutrients, main micronutrients, and fibers). Additionally, it limits the supply of sweets, sodium, and preparations containing added sugar.

Still, studies on the theme (school menu planning) should increase their depth and also consider the socio-environmental dimensions and appreciation of the food culture, as recommended by public policies. The literature contains gaps regarding the characterization and differentiation of regional foods from sustainable foods. A regional food may not promote sustainability depending on their production model, which raises the need of mapping these foods/products in future studies and deepening this discussion.

\section{CONCLUSION}

The study sample came from menus of municipalities of Santa Catarina that claimed to buy organic foods in 2010. However, these foods were not identified in the menus, evidencing the need of valuing this information in the planned menus and increasing the use of these foods to promote healthy food practices.

In this study, almost all menus had been planned by dieticians. However, some menus needed revision regarding the presence and frequency of fruits and non-starchy vegetables. Furthermore, the presence and frequency of whole grains also need to increase, while those of high-sugar, high-fat, and high-sodium foods, such as chocolate milk, biscuits, and commercially processed foods need to decrease. The variety of foods in the meals should also increase, avoiding color, food, and preparation technique monotony.
The menus should be revised to include specifications, such as preparation name, ingredients, and preparation technique.

We emphasize that school food should be a strategy to promote local and sustainable development, as recommended by PNAE, and that menu planning has an essential role in meeting these guidelines because the menu is an important instrument that can guide and encourage the production and acquisition of sustainable foods, and consequently promote healthy food practices.

\section{ACKNOWLEDGMENTS}

The authors thank Coordenação de Aperfeiçoamento de Pessoal de Nível Superior for providing the student grant, and the Centro Colaborador em Alimentação e Nutrição do Escolar de Santa Catarina and Fundo Nacional de Desenvolvimento da Educação - Brazilian Ministry of Education for sponsoring the study.

\section{CONTRIBUTORS}

GM VIDAL, MB VEIROS, and AA SOUSA participated in study conception and design, data analysis, and article writing and review.

\section{REFERENCES}

1. Brasil. Ministério da Saúde. Secretaria de Atenção à Saúde. Guia alimentar para a população brasileira: promovendo a alimentação saudável. Brasília: Ministério da Saúde; 2008 [acesso 2013 abr 16]. Disponível em: http://189.28.128.100/nutricao/ docs/geral/guia_alimentar_conteudo.pdf

2. Brasil. Ministério da Saúde. Secretaria de Atenção à Saúde. Política nacional de alimentação e nutrição. Brasília: Ministério da Saúde; 2012 [acesso 2013 abr 16]. Disponível em: http://189.28.128.1 00/nutricao/docs/geral/pnan2011.pdf

3. Brasil. Ministério da Saúde. Secretaria de Atenção à Saúde. Guia alimentar para a população brasileira. $2^{a}$ ed. Brasília: Ministério da Saúde; 2014 [acesso 2014 dez 2]. Disponível em: http://portalsaude. saude.gov.br/images/pdf/2014/novembro/05/GuiaAlimentar-para-a-pop-brasiliera-Miolo-PDFInternet.pdf 
4. World Health Organization. Global strategy on diet, physical activity and health. Geneva: WHO; 2004 [cited 2012 Oct 25]. Available from: http://www. who.int/dietphysicalactivity/strategy/eb11344/ strategy_english_web.pdf

5. Currie C, Gabhainn SN, Godeau E, Roberts C, Smith $\mathrm{R}$, Currie $\mathrm{D}$, et al. Inequalities in young people's health: Health behaviour in school-aged children international report from the 2005/2006 survey. Copenhagen: World Health Organization; 2008. Health Policy for Children and Adolescents, $n^{\circ} 5$ [cited 2014 Dec 2]. Available from: http://www. euro.who.int/_data/assets/pdf_file/0005/53852/ E91416.pdf?ua=1

6. Malta DC, Sardinha LMV, Barreto SM, Giatti L, Castro IRR, Moura L, et al. Prevalência de fatores de risco e proteção de doenças crônicas não transmissíveis em adolescentes: resultados da Pesquisa Nacional de Saúde do Escolar (PENSE), Brasil, 2009. Ciênc Saúde Colet. 2010; 15(Supl. 2):3009-19. http://dx.doi.org/10.1590/S1413-8123201000 0800002

7. Instituto Brasileiro de Geografia e Estatística. Pesquisa Nacional de Saúde do Escolar 2009: avaliação do estado nutricional dos escolares do $9^{\circ}$ ano do Ensino Fundamental. Rio de Janeiro: IBGE; 2010.

8. Brasil. Conselho Nacional Segurança Alimentar e Nutricional. A segurança alimentar e nutricional e o direito humano à alimentação adequada no Brasil: indicadores e monitoramento: da Constituição de 1988 aos dias atuais. Brasília: Consea; 2010 [acesso 2013 abr 16]. Disponível em: http://www4. planalto.gov.br/consea/publicacoes/publiucacoesarquivos/a-seguranca-alimentar-e-nutricional-e-odireito-humano-a-alimentacao-adequada-no-brasil

9. Brasil. Lei $n^{\circ} 11.947$, de 16 de junho de 2009. Dispõe sobre o atendimento da alimentação escolar e do Programa Dinheiro Direto na escola aos alunos da educação básica. Diário Oficial da União. 2009; 17 jun, p.24, Seção 1.

10. Brasil. Resolução/CD/FNDE n 38, 16 de julho de 2009. Dispõe sobre o atendimento da alimentação escolar aos alunos da educação básica no Programa Nacional de Alimentação Escolar (PNAE). Brasília: Fundo Nacional de Desenvolvimento da Educação; 2009.

11. Brasil. Decreto n 7.794, de 20 de agosto de 2012. Institui a Política Nacional de Agroecologia e Produção Orgânica. Diário Oficial da União. 2012; 21 ago, p.4-5, Seção 1.

12. Sousa AA, Azevedo E, Lima EE, Silva APF. Alimentos orgânicos e saúde humana: estudo sobre as controvérsias. Rev Panam Salud Publica. 2012; 31(6):513-7. http://dx.doi.org/10.1590/S1020-49 892012000600010
13. Food and Agriculture Organization. Agricultura mundial: hacia lós anos 2015/2030: informe resumido. Roma: FAO; 2002 [acceso 2014 dic 2]. Disponible en http://www.fao.org/docrep/004/ y3557s/y3557s00.htm

14. Domene SMA, Pereira TC, Arrivillaga RK. Estimativa da disponibilidade de zinco em refeições com preparações padronizadas da alimentação escolar do município de Campinas. Rev Nutr. 2008; 21(2):161-7. http://dx.doi.org/10.1590/S1415-52 732008000200004

15. Abranches MV, Paula HAA, Mata GMSC, Salvador BC, Marinho MS, Priore SE. Avaliação da adequação alimentar de creches pública e privada no contexto do programa nacional de alimentação escolar. Rev Nutrire. 2009; 34(2):43-57.

16. Menegazzo M, Fracalossi K, Fernandes AC, Medeiros NI. Avaliação qualitativa das preparações do cardápio de centros de educação infantil. Rev Nutr. 2011; 24(2):243-51. http://dx.doi.org/10.15 90/S1415-52732011000200005

17. Longo-Silva G, Toloni M, Rodrigues S, Rocha A, Taddei JAAC. Qualitative evaluation of the menu and plate waste in public day care centers in São Paulo city, Brazil. Rev Nutr. 2013; 26(2):135-44. http://dx.doi.org/10.1590/S1415-5273201300 0200002

18. Gabriel CG, Costa LCF, Calvo MCM, Vasconcelos FAG. Planejamento de cardápios para escolas públicas municipais: reflexão e ilustração desse processo em duas capitais brasileiras. Rev Nutr. 2012; 25(3):363-72. http://dx.doi.org/10.1590/S14 15-52732012000300006

19. Silva APF, Sousa AA. Alimentos orgânicos da agricultura familiar no Programa Nacional de alimentação Escolar do Estado de Santa Catarina, Brasil. Rev Nutr. 2013; 26(6):701-14. http://dx.doi. org/10.1590/S1415-52732013000600009

20. Veiros MB, Martinelli SS. Avaliação qualitativa das preparações do cardápio escolar: AQPC Escola. Nutrição em Pauta. 2012; 20(114):3-12.

21. Brasil. Instituto Brasileiro de Geografia e Estatística. Síntese de indicadores sociais: uma análise das condições de vida da população brasileira. Rio de Janeiro: IBGE; 2010 [acesso 2013 abr 16]. Disponível em: http://www.ibge.gov.br/home/estatistica/ populacao/condicaodevida/indicadoresminimos/ sinteseindicsociais2010/SIS_2010.pdf

22. Saraiva EB, Silva APF, Sousa AA, Cerqueira GF, Chagas CMS, Toral N. Panorama da compra de alimentos da agricultura familiar para o Programa Nacional de Alimentação Escolar. Ciênc Saúde Colet. 2013; 18(4):927-35. http://dx.doi.org/10.15 90/S1413-81232013000400004 
23. Lima EED, Sousa AA. Alimentos orgânicos na produção de refeições escolares: limites e possibilidades em uma escola pública de Florianópolis. Rev Nutr. 2011; 24(2):263-73. http://dx.doi.org/10.1590/ S1415-52732011000200007

24. Silvério GA, Sousa AA. Organic foods from family farms in the National School Food Program: Perspectives of social actors from Santa Catarina, Brazil. Rev Nutr. 2014; 27(3):289-300. http://dx.doi. org/10.1590/1415-52732014000300003

25. Carvalho AT, Muniz VM, Gomes JF, Samico I. Programa de alimentação escolar no município de João Pessoa - PB, Brasil: as merendeiras em foco. Interface. 2008; 12(27):823-34.

26. Neelon SEB, Copeland KA, Ball SC, Bradley L, Ward DS. Comparison of menus to actual foods and beverages served in North Carolina child-care centers. J Am Diet Assoc. 2010; 110(12):1890-5. http://dx.doi.org/10.1016/j.jada.2010.09.012

27. World Health Organization. Food and Agricultural Organization of the United Nations. Expert report on diet, nutrition and the prevention of chronic diseases. Geneva: WHO/FAO; 2003 [cited 2013 Apr 16]. WHO Technical Report Series, 916. Available from: http://www.fao.org/english/newsroom/news/ 2003/16851-en.html

28. Teo CRPA, Monteiro CA. Marco legal do Programa Nacional de Alimentação Escolar: uma releitura para alinhar propósitos e práticas na aquisição de alimentos. Rev Nutr. 2012; 25(5):657-68. http:// dx.doi.org/10.1590/S1415-52732012000500010

29. Condon EM, Crepinsek MK, Fox MK. School meals: types of foods offered to and consumed by children at lunch and breakfast. J Am Diet Assoc. 2009; 109(2 Suppl.):S67-78. http://dx.doi.org/10.1016/ j.jada.2008.10.062

30. Brasil. Resolução n 26, de 17 de junho de 2013. Dispõe sobre o atendimento da alimentação escolar aos alunos da educação básica no âmbito do Programa Nacional de Alimentação Escolar - PNAE. Brasília: Fundo Nacional de Desenvolvimento da Educação; 2013 [acesso 2013 ago 01]. Disponível em: http://www.fnde.gov.br/fnde/legislacao/ resolucoes/item/4620-resolução-cd-fnde-nº-26,de-17-de-junho-de-2013

Received: June 24, 2014

Final version: January 5, 2015

Approved: January 12, 2015 
